\title{
Metabolic crosstalk between fatty pancreas and fatty liver: effects on local inflammation and insulin secretion
}

\author{
Felicia Gerst ${ }^{1,2,3}$ - Robert Wagner ${ }^{1,2,3}$ - Gabriele Kaiser ${ }^{1,2,3} \cdot$ Madhura Panse $^{2,3}$. \\ Martin Heni ${ }^{1,2,3}$ - Jürgen Machann ${ }^{1,2,4}$ - Malte N. Bongers ${ }^{4}$ - Tina Sartorius ${ }^{2,3}$. \\ Bence Sipos $^{5}$ - Falko Fend ${ }^{5}$ - Christian Thiel ${ }^{6} \cdot$ Silvio Nadalin ${ }^{6} \cdot$ Alfred Königsrainer $^{6}$. \\ Norbert Stefan 1,2,3 - Andreas Fritsche ${ }^{1,2,3}$ - Hans-Ulrich Häring ${ }^{1,2,3}$. \\ Susanne Ullrich ${ }^{1,2,3} \cdot$ Dorothea Siegel-Axel ${ }^{1,2,3}$
}

Received: 29 September 2016 / Accepted: 15 June 2017 / Published online: 8 August 2017

(C) Springer-Verlag GmbH Germany 2017

\begin{abstract}
Aims/hypothesis Obesity-linked ectopic fat accumulation is associated with the development of type 2 diabetes. Whether pancreatic and liver steatosis impairs insulin secretion is controversial. We examined the crosstalk of human pancreatic fat cells with islets and the role of diabetogenic factors, i.e. palmitate and fetuin-A, a hepatokine released from fatty liver.

Methods Human pancreatic resections were immunohistochemically stained for insulin, glucagon, somatostatin and the macrophage/monocyte marker CD68. Pancreatic adipocytes were identified by Oil Red $\mathrm{O}$ and adiponectin staining.
\end{abstract}

Susanne Ullrich and Dorothea Siegel-Axel share senior authorship.

Electronic supplementary material The online version of this article (doi:10.1007/s00125-017-4385-1) contains peer reviewed but unedited supplementary material, which is available to authorised users.

Felicia Gerst

felicia.gerst@med.uni-tuebingen.de

1 Institute for Diabetes Research and Metabolic Diseases of the Helmholtz Center Munich at the Eberhard Karls University of Tuebingen (IDM), Tuebingen, Germany

2 German Center for Diabetes Research (DZD), Tuebingen, Germany

3 Department of Internal Medicine IV, University Hospital Tuebingen, Otfried-Mueller Street 10, 72076 Tuebingen, Germany

4 Section of Experimental Radiology, Department of Diagnostic and Interventional Radiology, University Hospital Tuebingen, Tuebingen, Germany

5 Department of General Pathology and Pathological Anatomy, University Hospital Tuebingen, Tuebingen, Germany

6 Department of General, Visceral and Transplant Surgery, University Hospital Tuebingen, Tuebingen, Germany
Primary pancreatic pre-adipocytes and differentiated adipocytes were co-cultured with human islets isolated from organ donors and the metabolic crosstalk between fatty liver and fatty pancreas was mimicked by the addition of palmitate and fetuin-A. Insulin secretion was evaluated by ELISA and RIA. Cytokine expression and secretion were assessed by RTPCR and multiplex assay, respectively. Subcellular distribution of proteins was examined by confocal microscopy and protein phosphorylation by western blotting.

Results In human pancreatic parenchyma, highly differentiated adipocytes were detected in the proximity of islets with normal architecture and hormone distribution. Infiltration of adipocytes was associated with an increased number of CD68positive cells within islets. In isolated primary pancreatic preadipocytes and differentiated adipocytes, palmitate and fetuinA induced $I L 6, C X C L 8$ and $C C L 2$ mRNA expression. Cytokine production was toll-like receptor 4 (TLR4)-dependent and further accentuated in pre-adipocytes when cocultured with islets. In islets, IL6 and CXCL8 mRNA levels were also increased by fetuin-A and palmitate. Only in macrophages within the isolated islets, palmitate and fetuin-A stimulated the production of the cytotoxic cytokine IL-1 $\beta$. Palmitate, but not fetuin-A, exerted pro-apoptotic effects in islet cells. Instead, fetuin-A impaired glucose-induced insulin secretion in a TLR4-independent, but c-Jun N-terminal kinase- and $\mathrm{Ca}^{2+}$-dependent, manner.

Conclusions/interpretation These results provide the first evidence that fetuin-A-mediated metabolic crosstalk of fatty liver with islets may contribute to obesity-linked glucose blindness of beta cells, while fatty pancreas may exacerbate local inflammation.

Keywords Adipocytes · Beta cells · Fetuin-A · Inflammation $\cdot$ Islets $\cdot$ Palmitate $\cdot$ TLR4 


$\begin{array}{ll}\text { Abbreviations } \\ \text { CT } & \text { Computed tomography } \\ \text { GIIS } & \text { Glucose-induced insulin secretion } \\ \text { hSA } & \text { human serum albumin } \\ \text { HU } & \text { Hounsfield units } \\ \text { IGI } & \text { Insulinogenic index } \\ \text { JNK } & \text { c-Jun N-terminal Kinase } \\ \text { LPS } & \text { Lipopolysaccharide } \\ \text { MCP-1 } & \text { Monocyte chemotactic protein-1 } \\ \text { TLR4 } & \text { Toll-like receptor } 4 \\ \text { WT } & \text { Wild-type }\end{array}$

\section{Introduction}

The role of pancreatic steatosis in the pathogenesis of type 2 diabetes is currently under discussion and may depend on additional risk factors [1-3]. Fat accumulation in the pancreas is associated with reduced insulin secretion in glucose intolerant humans [4]. However, it is controversial whether adipocyte infiltration and altered lipid profiles of pancreatic tissue affect islet function [4-8].

The secretomes of fatty liver and visceral adipocytes, including the hepatokine fetuin-A and NEFA, contribute to the generation of a diabetogenic milieu [9]. These factors favour low grade tissue inflammation and insulin resistance [10-14]. The ultimate cause of hyperglycaemia, however, is insufficient insulin secretion as a consequence of impaired glucoseinduced insulin secretion (GIIS), dedifferentiated beta cells or beta cell apoptosis [15-20].

NEFA- and cytokine-induced beta cell death has been extensively studied [10,21]. Multiple observations suggest that NEFA induce islet inflammation by stimulation of resident macrophages via activation of toll-like receptor 4 (TLR4) [22-25]. In addition, chemokine production (i.e. monocyte chemotactic protein-1 [MCP-1] and IL-8) within islets attracts macrophages [22].

Insulin resistance in humans is associated with high levels of NEFA only in the presence of elevated plasma fetuin-A, which indicates an interaction between fetuin-A and NEFA $[26,27]$. Besides its inhibitory effect on insulin receptors, fetuin-A, together with NEFA, induces inflammation in visceral adipocytes in a TLR4-dependent manner [28-30]. Recent evidence suggests that fetuin-A triggers M1 polarisation of adipose tissue macrophages [31]. However, fetuin-A, an abundant fetal serum protein, has multiple roles. As a $\mathrm{Ca}^{2+}$-binding protein it regulates $\mathrm{Ca}^{2+}$-phosphate homeostasis and calcification [32]. Fetuin-A binds NEFA and bacterial endotoxins and is a negative acute phase protein [33, 34].

Using an in vitro co-culture system of isolated human pancreatic pre-adipocytes and differentiated adipocytes with islets, we aimed to decipher potential mechanisms by which fatty liver-fatty pancreas crosstalk impairs islet function.
These mechanisms may reveal the pathogenic relevance of pancreatic steatosis for glucose homeostasis in humans.

\section{Methods}

Measurements of pancreatic fat and insulin secretion in humans Insulin sensitivity and secretion were assessed in non-diabetic participants $(n=121)$ using OGTTs. The anthropometric and metabolic characteristics of the cohort are shown in the electronic supplementary material (ESM) Table 1. Impaired glucose tolerance was defined as post-challenge glucose $>7.8 \mathrm{mmol} / \mathrm{l}$. Insulin secretion was assessed by the insulinogenic index (IGI; insulin $30-$ insulin $_{0}[\mathrm{pmol} / \mathrm{l}]$ )/ (glucose $_{30}-$ glucose $\left._{0}[\mathrm{mmol} / \mathrm{l}]\right)$ or $\left(\mathrm{C}-\right.$ peptide $\left._{(0-30)}[\mathrm{ng} / \mathrm{ml}]\right) /$ (AUC glucose $(0-30)$ ). Whole body fat distribution was estimated by MRI as previously described [4, 35].

Assessment of in vivo beta cell function with the disposition index The disposition index (IGI $\times$ insulin sensitivity index) provides a measure of beta cell function in vivo, as it takes the respective insulin sensitivity into account. An OGTT was conducted before pancreatic surgery, and blood glucose $(\mathrm{mmol} / \mathrm{l})$ and plasma insulin $(\mathrm{pmol} / \mathrm{l})$ were measured at 0,30 , 60, 90 and $120 \mathrm{~min}$. The IGI was as described above. Insulin sensitivity was estimated using the Matsuda index $\left(10^{4} /\right.$ $\left(\mathrm{G}_{0} \times \mathrm{I}_{0} \times\left(\mathrm{G}_{0}+\mathrm{G}_{30}+\mathrm{G}_{60}+\mathrm{G}_{90}+\mathrm{G}_{120}\right) / 5\right) \times\left(\mathrm{I}_{0}+\mathrm{I}_{30}+\mathrm{I}_{60}+\mathrm{I}_{90}+\mathrm{I}_{120}\right) /$ $\left.5)^{0.5}\right)$.

Human pancreatic resections and evaluation of pancreatic steatosis Pancreatic resections (90 individuals, age 5775 years, BMI $22.4-27.6 \mathrm{~kg} / \mathrm{m}^{2}$ ) were taken from a tumourfree region. The fat content of the whole pancreas was estimated by computed tomography (CT) in 26 participants for whom adipocyte infiltration was histologically characterised. Regions of interest were drawn in unenhanced axial slices to determine Hounsfield units (HU) in the head, body and tail of the pancreas, and the mean was calculated. A fat-free pancreas exhibits a density of 40-50 HU and adipose tissue about -90 HU.

Human islets and single cell preparation Human islets were cultured in CMRL-1066 (ESM Table 2). For immunohistochemistry, isolated islet cells were cultured overnight on glass coverslips coated with human collagen-1 [21]. Treatment with $0.6 \mathrm{mg} / \mathrm{ml}$ human fetuin-A (Sigma-Aldrich, Munich, Germany), human serum albumin (hSA, as control) and $60 \mu \mathrm{mol} / \mathrm{l}$ palmitate was performed in FCS-free (to avoid exposure to bovine fetuin-A) culture medium. The concentrations of palmitate and albumin were adapted to the concentration of $0.6 \mathrm{mg} / \mathrm{ml}$ fetuin-A which matches plasma levels in glucose intolerant humans [36]. 
Isolation, culture and differentiation of human pancreatic pre-adipocytes Pancreatic pre-adipocytes were isolated from adipose tissue obtained from the pancreatic resections as previously described [30]. Isolated pre-adipocytes were expanded in DMEM/Ham's mixture F12 (1:1, ESM Table 2). FACS analysis with FITC-coupled anti-CD31 and anti-CD14 antibodies (ESM Table 3 ) precluded contamination with endothelial cells and monocytes/macrophages, respectively.

Adipose conversion was conducted for 7 days in DMEM/Ham's mixture F12 (1:1, ESM Table 2). The cells were terminally differentiated for a further 7 days in medium without supplements.

\section{Co-culture of human pancreatic fat cells and islets} Pancreatic pre-adipocytes and adipocytes were used at confluence. Human islets were placed in inserts which allows a separate analysis of fat cells and islets and media from the distinct compartments. Mono- and co-cultures were performed for $24 \mathrm{~h}$ in FCS-free human islet culture medium supplemented with fetuin-A, hSA and palmitate.

Gene expression Total RNA of islets and fat cells were isolated (Nucleo Spin RNAII, Macherey-Nagel, Dueren, Germany) and transcribed using random primers (Transcriptor First Strand kits, Roche Diagnostics, Rotkreuz, Switzerland). PCR primers and probes (Light Cycler 480 System, Roche Diagnostics) are listed in ESM Table 4. Normalised gene expression was calculated as a ratio of $\mathrm{C}_{\mathrm{t}}$ of target vs housekeeping gene (RPS13) transcripts $\left(2^{-\Delta \mathrm{C}_{\mathrm{t}}}\right.$,

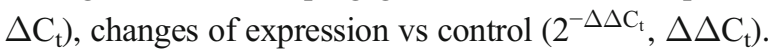

Cytokine and insulin quantification Secreted cytokines were quantified using the XMAP technology (Luminex, BioRad Laboratories, Munich, Germany). Bio-Plex Pro Human Cytokine-1 5-plex EXPRESS-Kit (BioRad Laboratories) and the Human Luminex Screening Assay LXSAH-06 (R\&D Systems, Minneapolis, MN, USA) were used to quantify IL- 6 , IL- 8, MCP- 1 and IL- $1 \beta$ proteins. Insulin was measured by RIA (Merck Millipore, Darmstadt, Germany).

Immunohistochemistry Paraffin-embedded serial sections from 50 participants were incubated with primary antibodies (ESM Table 3). H\&E was used for counterstaining. Macrophage/monocyte infiltration was quantified by counting the CD68-positive cells in islets without adipocytes in their proximity vs islets neighbouring adipocytes at a distance $<400 \mu \mathrm{m}$. Lipids droplets were visualised using Oil Red O $(0.5 \%$ in propylene glycol) after fixation of pancreatic cryosections with $4 \%$ formalin and dehydration with $100 \%$ propylene glycol.
Human islet cells were fixed with $4 \%$ formalin, permeabilised with $0.2 \%$ Triton X-100 (Sigma-Aldrich, Munich, Germany) and incubated for $1 \mathrm{~h}$ in $10 \%$ FCS-PBS. Primary anti-p65NFkB antibody was added overnight and secondary antibody for $1 \mathrm{~h}$. Nuclei were stained with $1 \mu \mathrm{mol} / 1$ TO-PRO-3. TUNEL staining was performed according to the protocol provided with the kit (Roche Diagnostics).

Western blotting Treated islets were lysed in RIPA buffer (ESM Table 2). Proteins were resolved using 10\% SDSPAGE and blotted onto nitrocellulose membranes. Membranes were incubated in 5\% (wt/vol.) milk TBSTween 20 overnight with primary antibodies and for $1 \mathrm{~h}$ with a horse radish peroxidase-coupled secondary antibody (ESM Table 3).

Isolation, culture and insulin secretion of mouse islets Wild-type (WT) (C57BL/6NCrl and $\mathrm{C} 3 \mathrm{H} / \mathrm{HeNCrl})$ and TLR4-defective $(\mathrm{C} 3 \mathrm{H} / \mathrm{HeJ})$ mouse islets were isolated using collagenase as previously described [21]. Islets were cultured in RPMI1640 (ESM Table 2). For macrophage depletion, islets were cultured for 2 days in the presence of $0.5 \mathrm{mg} / 1$ clodronate- or PBS (control)-containing liposomes. Afterwards, islets were cultured for $24 \mathrm{~h}$ or $48 \mathrm{~h}$ in FCS-free medium with fetuin-A, hSA and $10 \mu \mathrm{mol} / 1 \mathrm{SP} 600125$ (a c-Jun N-terminal kinase [JNK] inhibitor). Insulin secretion (10 islets $/ 500 \mu \mathrm{l}$ ) was performed in $\mathrm{KRB}$ containing: $135 \mathrm{mmol} / \mathrm{l}$ $\mathrm{NaCl}, 4.8 \mathrm{mmol} / 1 \mathrm{KCl}, 1.2 \mathrm{mmol} / \mathrm{l} \mathrm{Mg}_{2} \mathrm{SO}_{4}, 1.2 \mathrm{mmol} / 1$ $\mathrm{KH}_{2} \mathrm{PO}_{4}, 1.3 \mathrm{mmol} / 1 \mathrm{CaCl}_{2}, 5 \mathrm{mmol} / 1 \mathrm{NaHCO}_{3}, 10 \mathrm{mmol} / \mathrm{l}$ HEPES (pH 7.4), 0.5\% (wt/vol.) BSA (fraction V) and glucose as indicated. Secreted insulin and insulin content after extraction with acid ethanol (1.5\% (vol./vol.) $\mathrm{HCl} / 75 \%$ (vol./ vol.) ethanol) were measured by ELISA.

Statistics Human tissue and cell samples were blinded before use and randomised to the treatment. Islets and islet cells were randomly distributed between the treatment groups. Statistical analysis was performed with random-intercept linear mixed models, using donors as random effects and treatments as fixed effects. The Tukey honest significant difference (HSD) test was used as post hoc test. A $p$ value $<0.05$ was considered to be significant.

Study approval All experiments with human material were approved by the Ethics Commission of the Medical Faculty and the University Hospital of the University of Tuebingen (No. 697/2011BO1 and 355/2012BO2). All participants gave informed written consent.

Isolation of mouse islets was conducted in accordance with the accepted standard of animal care and was approved by the local authorities. 


\section{Results}

Negative correlation of pancreatic fat content with insulin secretion in humans The relevance of pancreatic fat for islet function was re-evaluated in a well-defined cohort of 121 nondiabetic humans (Fig. 1a, b). While pancreatic fat content did not correlate with insulin secretion in individuals with normal glucose tolerance (Fig. 1a, $\beta=0.079, p=0.38$; for IGI: $\beta=0.068, p=0.54$ ) it negatively correlated with insulin secretion in humans with impaired glucose tolerance (Fig. $1 \mathrm{~b}, \beta=-1.2, p=0.0031$; for IGI: $\beta=-1.6$, $p=0.0009$ ). This result supports our previous observation [4].

Identification of adipocytes in human pancreatic parenchyma Ectopic fat accumulation in the pancreas was characterised in 90 pancreatic resections. Differentiated adipocytes with a large lipid droplet and cytosolic adiponectin staining infiltrated the pancreatic tissue of $70 \%$ of the participants (Fig. 1c, d). The histological assessment of adipocyte infiltration correlated with the degree of pancreatic steatosis evaluated in the whole organ by CT measurements (ESM Fig. 1). Irrespective of the degree of adipocytes infiltration the islets displayed a normal architecture (Fig. 1e-g and ESM Fig. 2a). Most of the cells in the islet core stained for insulin, while the glucagon-containing cells were located peripherally in small and randomly in large islets, as previously reported [37]. A small number of cells stained positive for somatostatin (Fig. 1g). It is worth mentioning that even neighbouring islets displayed large variations in the proportion and distribution of glucagon-positive cells (ESM Fig. 2b).

Primary pancreatic pre-adipocytes and adipocytes are differentially stimulated by palmitate, fetuin-A and islets in co-culture Pre-adipocytes were isolated from pancreatic
Fig. 1 Pancreatic fat content negatively correlates with insulin secretion in humans with impaired glucose tolerance. $(\mathbf{a}, \mathbf{b})$ Association of MRI-measured pancreatic fat content with insulin secretion expressed as $\mathrm{AUC}(\mathrm{C}$ peptide)/AUC(glucose) in individuals with (a) normal glucose tolerance $(\beta=0.079$, $p=0.38)$ and $(\mathbf{b})$ impaired glucose tolerance $(\beta=-1.2$, $p=0.0031)$. Data were adjusted for insulin sensitivity using multivariate linear regression modelling. (c-g) Representative pictures of human pancreatic tissue from 90 participants that were stained for (c) lipid droplets (Oil Red O) and (d) adiponectin (brown, cytosolic vesicular staining) and (e-g) successive sections stained for (e) insulin, (f) glucagon and (g) somatostatin a

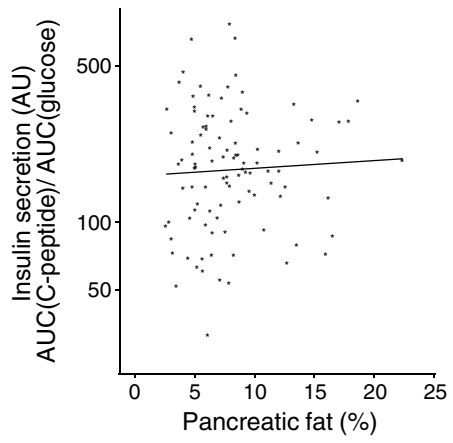

C

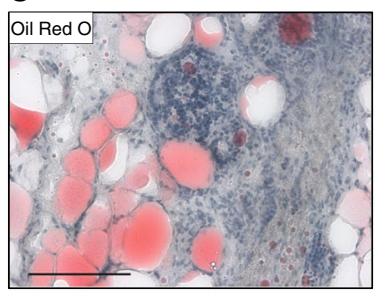

b

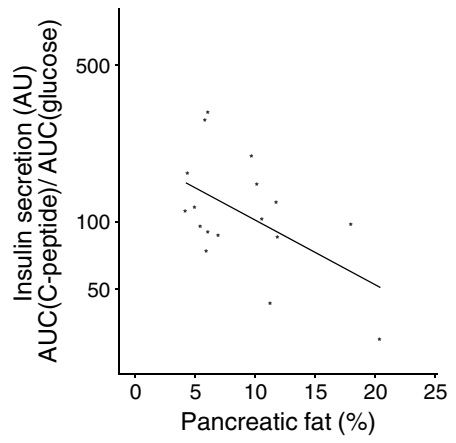

d

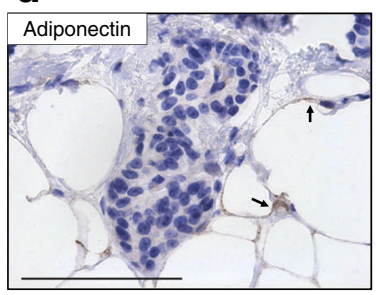

e
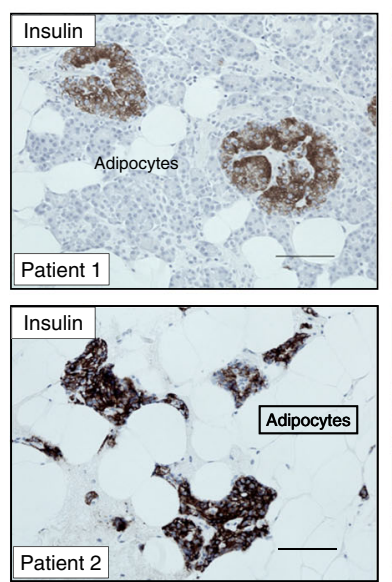

f
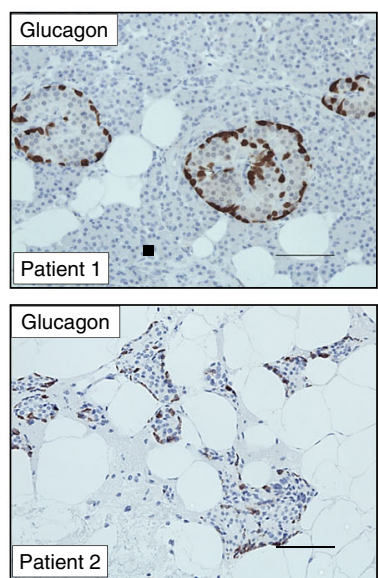

g

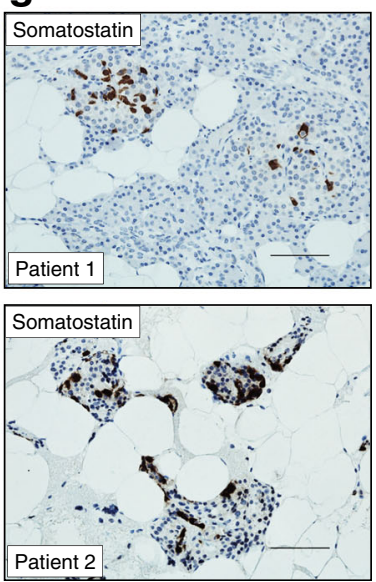


adipose tissue and, following expansion, were differentiated into adipocytes (ESM Fig. 3). Adipocytes differentiation was assessed by detection of lipid droplets and $A D I P O Q$ (encoding adiponectin) mRNA. The pre-adipocyte and adipocyte cultures were free of macrophages/monocytes, as IL-1 $\beta$ (IL1B) and TNF- $\alpha(T N F)$ were not detectable (data not shown). Under control conditions $(0.6 \mathrm{mg} / \mathrm{ml} \mathrm{hSA})$ the pre-adipocytes and adipocytes expressed low levels of IL6 (encoding IL-6), CXCL8 (IL-8) and CCL2 (MCP-1; Fig. 2a-f, first columns). Palmitate and fetuin-A stimulated $I L 6, C X C L 8$ and CCL2 expression in pre-adipocytes and adipocytes, respectively (Fig. 2a-f). As expected, the cytokine production (IL6, CXCL8 and CCL2) was completely inhibited by the TLR4 inhibitor CLI-095 (ESM Fig. 4). Further analysis revealed that mRNA levels of TGFB1 (TGF- $\beta 1$ ), TGFB3 (TGF- $\beta 3$ ), VEGF and $H G F$ remained unchanged (ESM Fig. 5).

In order to examine the paracrine crosstalk between human fat cells and islets an in vitro co-culture system was established. The co-culture with islets further increased IL6 mRNA levels of pre-adipocytes in the presence of fetuin-A, alone or with palmitate (Fig. 2g). Concurrently, CXCL8 and CCL2 mRNA levels were significantly increased by fetuin-A and palmitate (Fig. 2h, i). The rise in mRNA levels correlated with increased cytokine secretion enforcing paracrine action of pre-adipocytes on neighbouring cells (Fig. 2j-1). In contrast to the effect of islets on pre-adipocytes, cytokine production of
Fig. 2 Cytokine production of pancreatic pre-adipocytes and adipocytes is stimulated by fetuinA, palmitate and co-culture with isolated islets. $(\mathbf{a}-\mathbf{c})$ Preadipocytes $(n=10$ independent preparations) and (d-f) adipocytes $(n=7)$ were cultured for $24 \mathrm{~h}$ in the presence of test substances. Relative mRNA levels $\left(\Delta \mathrm{C}_{\mathrm{t}}\right.$ against RPS13). (g-l) Pre-adipocytes were co-cultured with isolated human islets $(n=5$ independent experiments) as described in the Methods. $(\mathbf{g}-\mathbf{i})$ The effect of islets on preadipocyte mRNA levels (the foldchange $\left[\Delta \Delta \mathrm{C}_{\mathrm{t}}\right]$ induced in preadipocytes by the co-culture with islets compared with monocultured pre-adipocytes under the same conditions, $n=5)$. ( $\mathbf{j}-\mathbf{l})$ Cytokine secretion in the preadipocytes compartment during mono-culture (black columns, $n=5$ ) and co-culture (hatched columns, $n=5$ ). Data are presented as mean $\pm \mathrm{SEM}$. $* p<0.05, * * p<0.01$, $* * * p<0.001$ vs respective control (hSA); ${ }^{\dagger} p<0.05$, ${ }^{\dagger} p<0.01,{ }^{\dagger} p<0.001$ coculture vs mono-culture under the same conditions. Adipo, adipocytes; hFet, fetuin-A; palm, palmitate; pre-adipo, preadipocytes
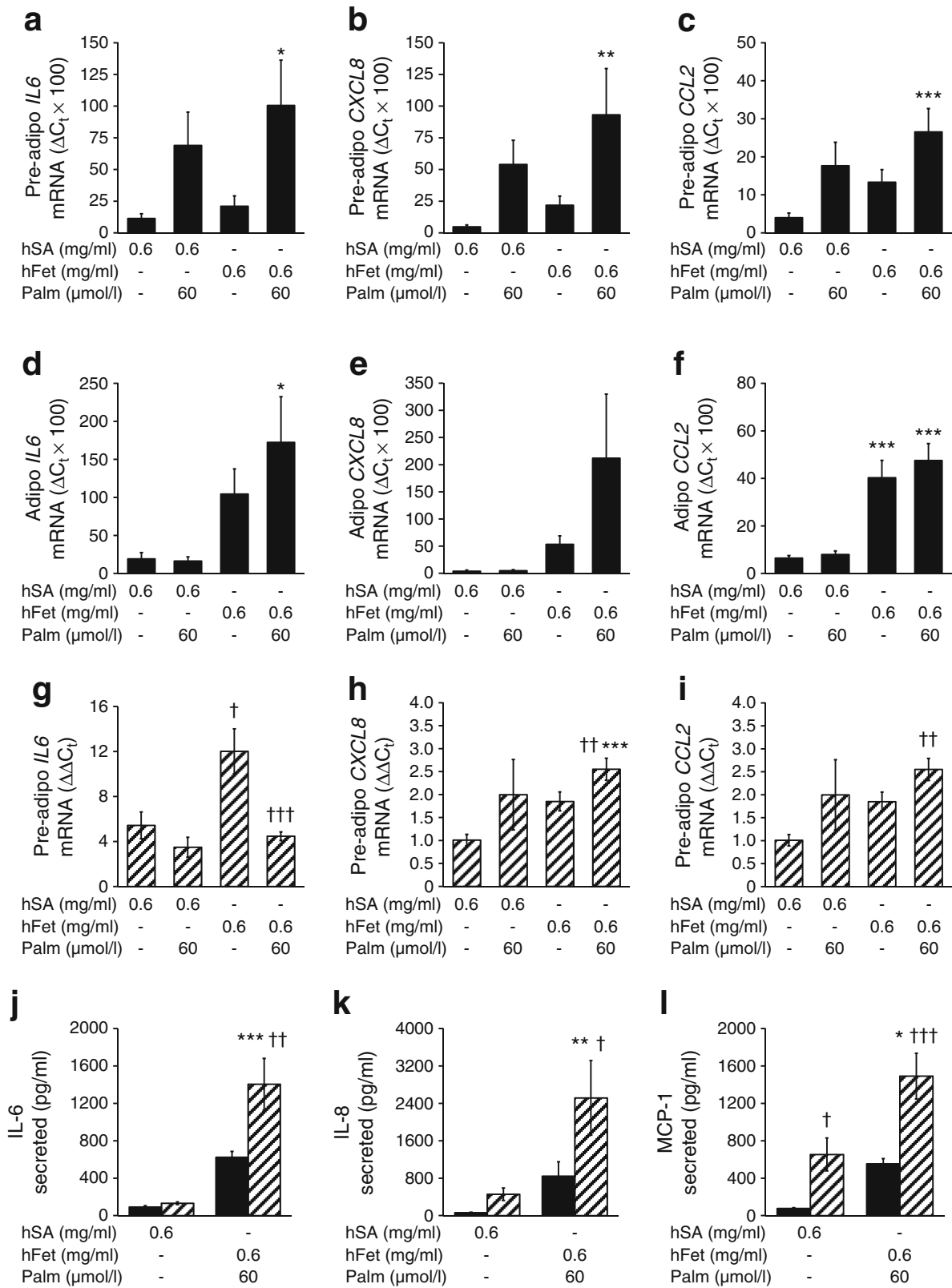

k

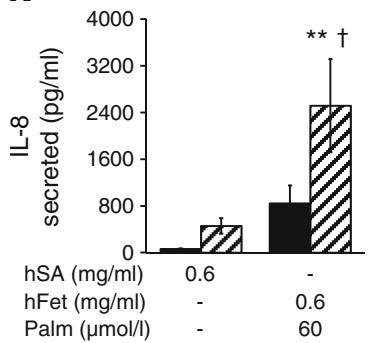

f

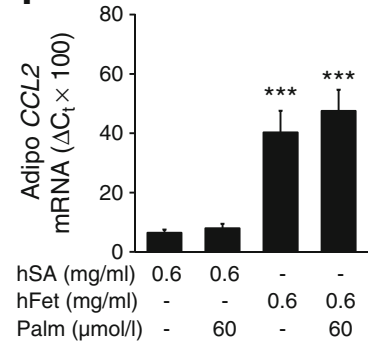

i

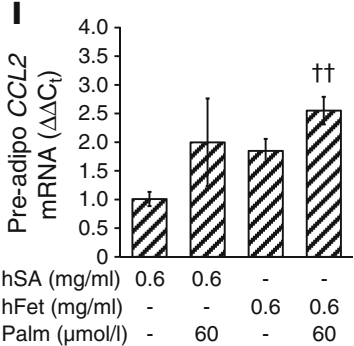

I

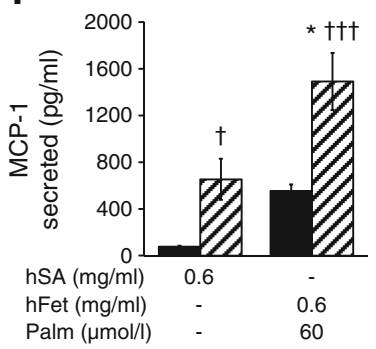


adipocytes was not altered by islets under all co-culture conditions (data not shown).

These experiments identify the pre-adipocytes and adipocytes as highly active cell populations in the pancreatic parenchyma which secrete IL-6, IL-8 and MCP-1 upon stimulation with diabetogenic factors.

Macrophages/monocytes infiltrate islets more abundantly in proximity to adipocytes Since fat cells produce chemoattractants, IL-8 and MCP-1, we next analysed whether pancreatic steatosis is associated with increased local inflammation. In human pancreatic resections, a significantly higher number of CD68-positive macrophages/monocytes were found in the islets located in proximity to adipocytes (Fig. $3 a-c)$. The mRNA analysis of laser-captured islets from pancreatic resections revealed a low expression of $I L 1 B$ mRNA irrespective of the degree of pancreatic steatosis (Fig. 3d). In isolated islets from organ donors, comparable amounts of IL1B mRNA were detected (Fig. 3e, first column). Fetuin-A increased $I L 1 B$ expression in isolated islets fourfold, an effect which was further augmented by the co-culture with preadipocytes in the presence of fetuin-A and palmitate (Fig. $3 e$, hatched bars).

Upon treatment of isolated islets with clodronate liposomes which selectively depleted resident macrophages, fetuin-Ainduced expression of ILIB was lost, while INS (encoding insulin) and CCL2 mRNA levels remained unchanged (Fig. $3 \mathrm{f}-\mathrm{h}$ ). Furthermore, inhibition of TLR 4 signalling by CLI-095 ( $5 \mu \mathrm{mol} / \mathrm{l})$ completely blocked fetuin-A-induced stimulation of ILIB and IL6 expression, whereas CCL2 mRNA levels were again not altered (Fig. 3i-k).

These observations suggest that pancreatic fat cells may accentuate macrophage/monocyte infiltration via a local production of IL-8 and MCP-1. The macrophages/monocytes, however, only secrete cytotoxic cytokines upon exposure to an adequate stimulus.

Similar to the stimulatory effect of fetuin-A and palmitate on IL6 and CXCL8 mRNA levels in fat cells, a minor but consistent increase was detectable in isolated islets (ESM Fig. 6f, g). FetuinA reduced $S L C 2 A 2$ (encoding GLUT-2) expression, while $T N F$, $C C L 2, B L C 2, T G F B 1, T G F B 3, V E G F$ and $H G F$ mRNA levels were not altered (ESM Fig. 6). The co-culture with neither preadipocytes nor adipocytes affected islet mRNA levels, i.e. INS, GCG, SST, PDXI and IRS2 (ESM Fig. 7).

\section{Fetuin-a exerts TLR4-independent effects in islet cells} Insufficient insulin secretion during obesity is thought to result from a reduced beta cell mass due to increased beta cell apoptosis. In isolated human islet cells the apoptotic rate was enhanced by palmitate (Fig. 4a). Fetuin-A did not amplify but reversed the cytotoxic effect of palmitate. The analysis of the underlying signalling pathways suggests that, in contrast to the TLR4 agonist lipopolysaccharide (LPS), palmitate and fetuin- $\mathrm{A}$, alone and together, triggered neither nuclear accumulation of NF- $\mathrm{KB}$ nor NF- $\mathrm{KB}$ phosphorylation at serine536 (Fig. 4b-e). A further indication that fetuin-A exerts TLR4-independent effects in islets was the stimulation of JNK phosphorylation in the presence of CLI-095 (Fig. 4f, g). Additional evidence for a TLR4-independent effect of fetuin-A was corroborated using TLR4-deficient mouse islets (Fig. 5). In agreement with the observation made in human islets, fetuin-A increased phosphorylation of JNK both in WT and TLR4-deficient mouse islets (Fig. 5a, b). The stimulation of JNK occurred in the absence of cytokines, since TLR4 deficiency abrogated the fetuin-A-induced increase of $I l 1 b$ and $I l 6$ mRNA levels (Fig. $5 \mathrm{c}$, d).

Next, we examined the effect of fetuin-A on insulin secretion in isolated islets from WT and TLR4-defective mice (Fig. 5e). Fetuin-A inhibited both GIIS and exendin-4-mediated augmentation of secretion in a TLR4-independent manner (Fig. 5e). When JNK was inhibited by SP600125 (10 $\mu \mathrm{mol} / 1$ during 2 days of fetuin-A treatment), fetuin-A-mediated inhibition of GIIS was completely abrogated suggesting that JNK conveys the negative effect of fetuin-A on secretion (Fig. 5f).

Previously, the inhibitory effect of JNK on GIIS has been linked to a reduced glucose-induced $\mathrm{Ca}^{2+}$ influx [38]. Since fetuin- $\mathrm{A}$ is a $\mathrm{Ca}^{2+}$-binding protein, we examined whether an increase of the extracellular $\mathrm{Ca}^{2+}$ concentration improves GIIS of fetuin-A-treated islets. The elevation of the extracellular $\mathrm{Ca}^{2+}$ concentration from 1.3 to $2.6 \mathrm{mmol} / \mathrm{l}$ augmented GIIS and antagonised the inhibitory effect of fetuin-A in mouse islets (Fig. 6a).

In isolated islets from human organ donors, the elevation of glucose from 2.8 to $12 \mathrm{mmol} / \mathrm{l}$, the doubling of the concentration of extracellular $\mathrm{CaCl}_{2}$ and the addition of palmitate $(600 \mu \mathrm{mol} / \mathrm{l})$ significantly increased insulin secretion in control islets (Fig. 6b). In islets exposed to fetuin-A, GIIS was abrogated and the stimulatory effect of $\mathrm{CaCl}_{2}$ was significantly impaired (Fig. 6b). Palmitate-mediated stimulation of insulin secretion remained unaltered by fetuin-A. That fetuin-A affects beta cell function in vivo is further suggested by the negative correlation of plasma fetuin-A levels with the disposition index which adjusts insulin secretion for insulin sensitivity (Fig. 6c, $R^{2}=0.45 ; p=0.033$ ).

These results strongly suggest that fetuin-A, by stimulating JNK and interfering with the $\mathrm{Ca}^{2+}$ homeostasis, compromises glucose sensitivity of human and mouse beta cells.

\section{Discussion}

This study highlights the role of metabolic crosstalk between the pancreas and liver in the development of type 2 diabetes. Not only are the beta cells directly targeted by diabetogenic factors, i.e. palmitate and fetuin-A, but so are the pancreatic pre-adipocytes and adipocytes. 
Fig. 3 Islet macrophages/ monocytes express cytotoxic cytokines. (a-c) A significantly higher number of CD68-positive cells were found in islets residing in the vicinity of adipocytes.

Shown are representative pictures of CD68 staining in (a)

'adipocyte-free' and (b) 'fatty' islets. The dotted boundaries in the figure enlargements mark the islet perimeter. (c) CD68-positive cell number determined in 388 'adipocyte-free' (Adipos-free) and 739 'fatty' (+Adipos) islets of 50 participants. (d) ILIB mRNA levels in laser-captured islets from five participants without (Adiposfree) and with (+Adipos) pancreatic steatosis. (e) $I L 1 B$ mRNA levels of isolated islets mono-cultured (white bars) and co-cultured (hatched bars) with pre-adipocytes in the presence of test substances for $24 \mathrm{~h}(n=5$ independent experiments). (f-h) Human islets $(n=3$ independent preparations) were cultured for $48 \mathrm{~h}$ in the presence of PBS or clodronate liposomes $(0.5 \mathrm{mg} / \mathrm{ml})$. Thereafter, the islets were cultured for $24 \mathrm{~h}$ in the presence of hSA or fetuin-A. (i-k) Human islets $(n=6$ independent preparations) were cultured for $24 \mathrm{~h}$ as indicated. IL 1B, CCL2, IL6 and INS mRNA levels are expressed as mean \pm SEM. $* p<0.05$, $* * * p<0.001$ vs hSA (or Adiposfree in a); ${ }^{\dagger \dagger} p<0.001$ vs fetuinA. CLI, CLI-095 (TLR4 inhibitor); Clodr-L., clodronate liposomes; hFet, fetuin-A; palm, palmitate

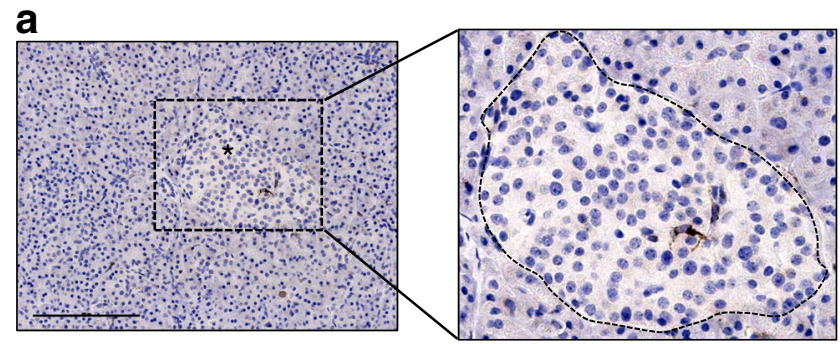

b
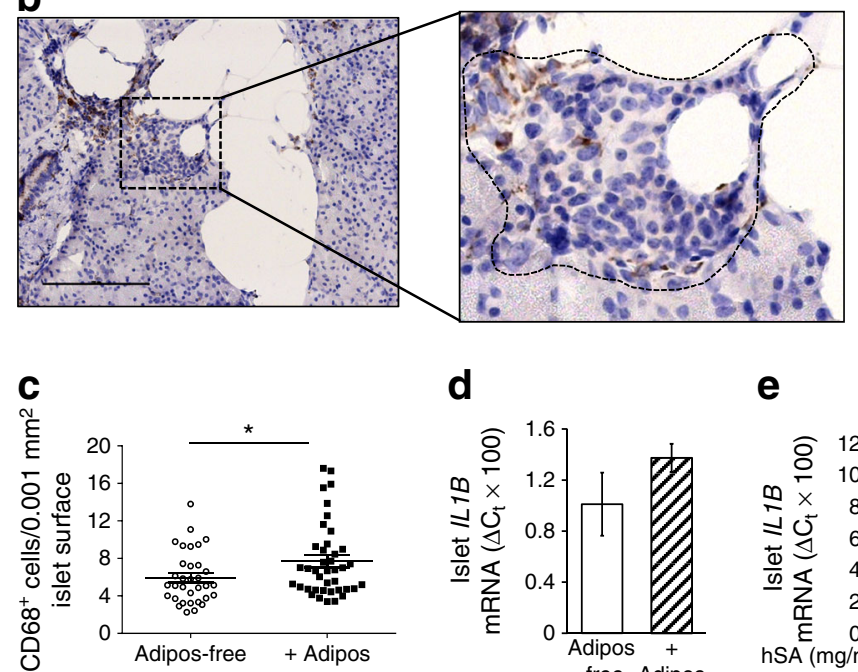

d

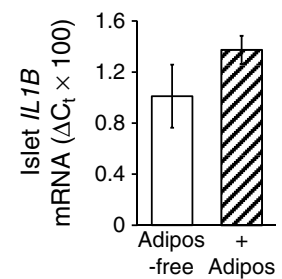

e

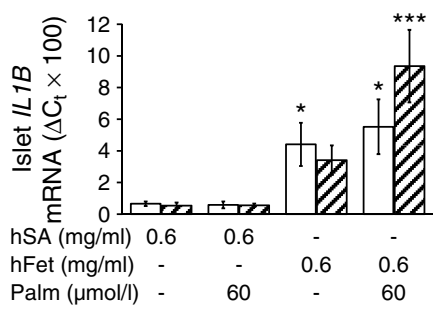

f
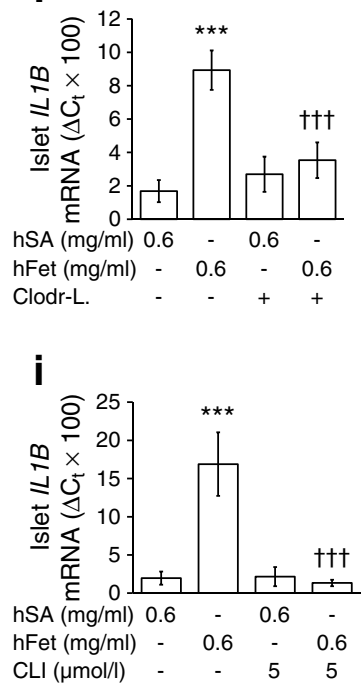

g
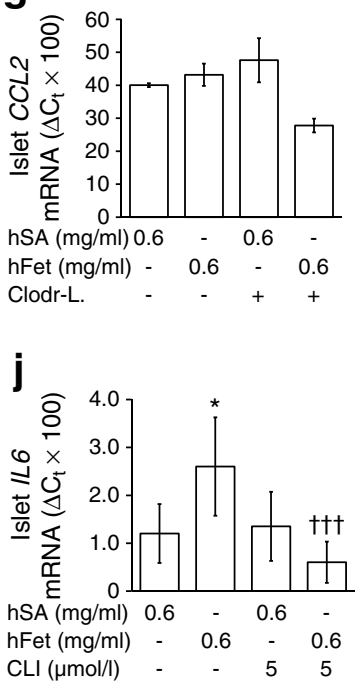

h

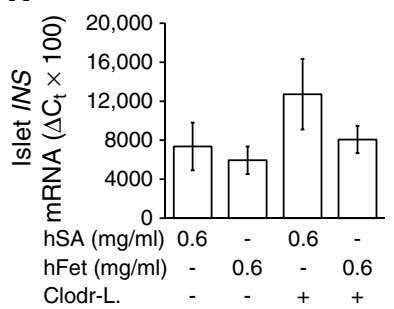

k

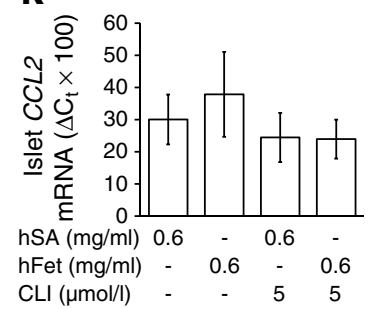

Pre-adipocytes and adipocytes contribute to pancreatic inflammation In this study we isolated pre-adipocytes and adipocytes from human pancreatic resections and characterised their proinflammatory potential. The isolation and in vitro differentiation enabled us to identify the pre-adipocytes as further operators of tissue inflammation. Interestingly, in coculture experiments the islets augmented the inflammatory response of pre-adipocytes. While insulin is a mandatory factor for adipocyte differentiation, local inflammation was also proposed to sustain adipogenesis [39, 40]. This could explain why highly differentiated adipocytes were detected throughout the pancreas.

Fetuin-A and palmitate induced chemokine (MCP-1 and IL-8) and cytokine (IL-6) production in human pancreatic pre-adipocytes and adipocytes. These findings reveal the fatty liver as an important player in fat cell inflammation and are in 
Fig. 4 TLR4-independent effects of fetuin-A in human islet endocrine cells. (a, b) Isolated human islet cells and (c-g) whole islets were cultured for (a) $24 \mathrm{~h}$ and $(\mathbf{b}-\mathbf{g}) 1 \mathrm{~h}$ as described in the Methods. (a) TUNEL staining is expressed as mean \pm SEM of $n=4$ independent experiments.

(b) Representative pictures from three independent experiments of subcellular distribution of p65NFKB (green); scale bar, $50 \mu \mathrm{m}$. Nuclei are stained in red (LPS, $1 \mu \mathrm{g} / \mathrm{ml}$ ). (c-g) Representative western blots for P-Ser536-NFкB, NF-kB, P-Thr183/Tyr185$\mathrm{JNK}, \mathrm{JNK}$ and mean \pm SEM of three independent experiments. GAPDH and tubulin were used as loading control. $* * p<0.01$, *** $p<0.001$ vs hSA; ${ }^{\dagger \dagger} p<0.01$ vs fetuin-A. CLI, CLI-095 (TLR4 inhibitor); hFet, fetuin-A; palm, palmitate
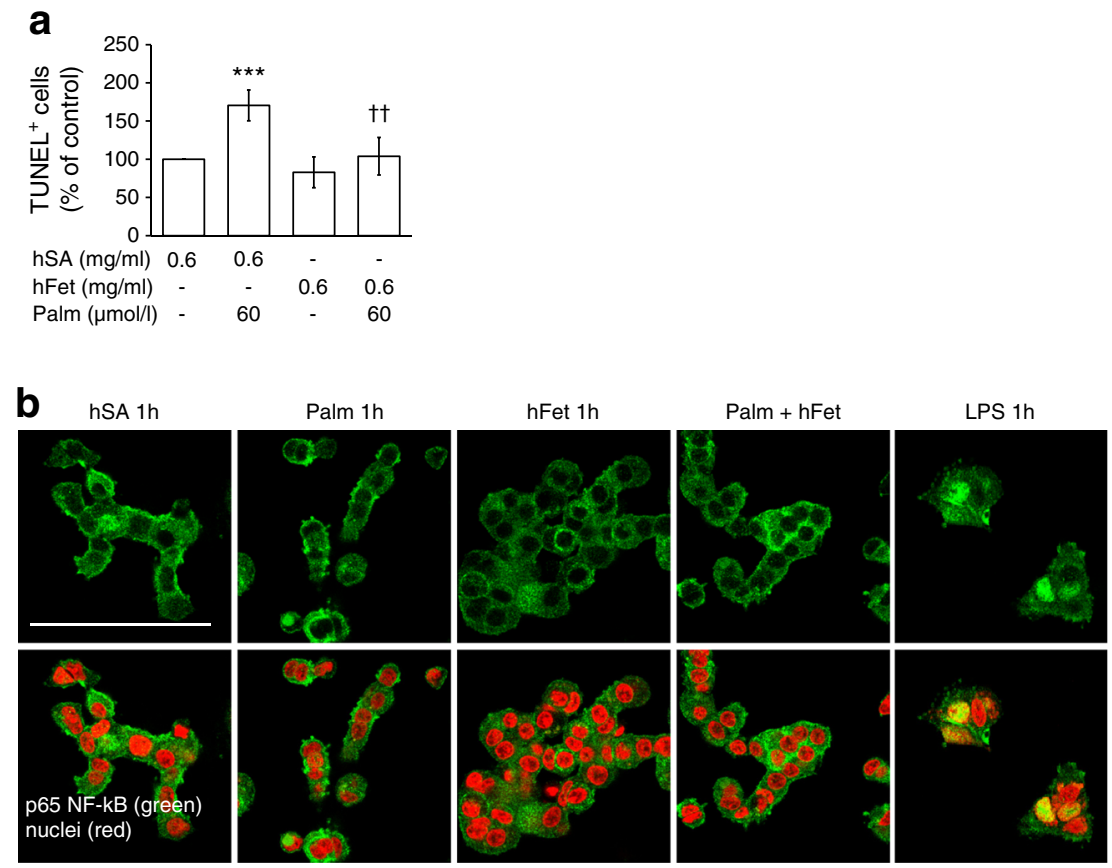

C

d
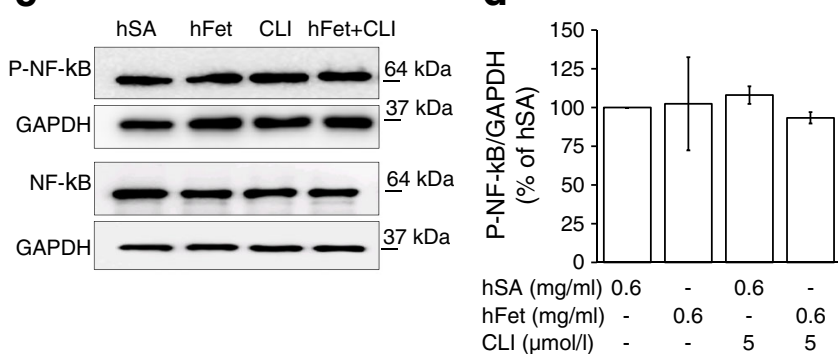

e
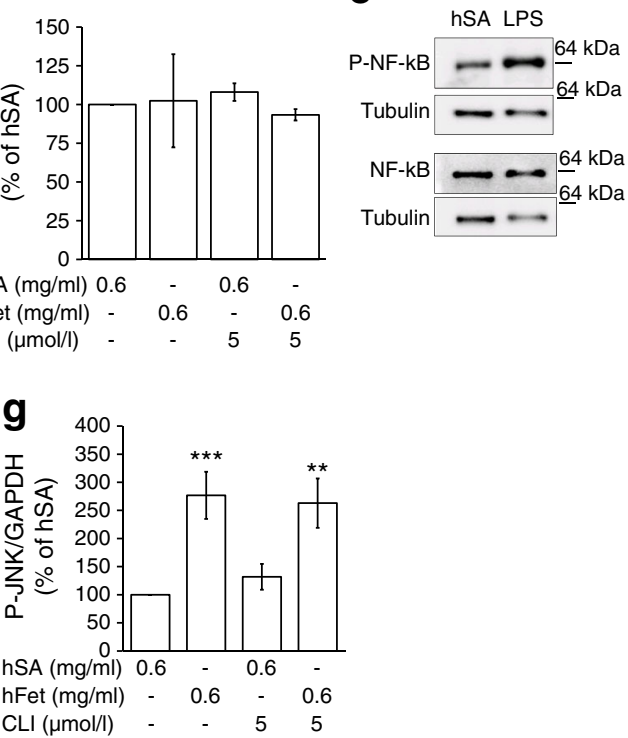

agreement with our previous studies using perivascular fat cells and the proposed proinflammatory effect of fetuin-A and palmitate via TLR4 stimulation [29, 30]. Thus, diabetesassociated factors, i.e. fetuin-A and NEFA, are putative potent activators of pancreatic fat cells.

In pancreatic resections, the adipocyte infiltration per se was not associated with altered islet architecture. Furthermore, the co-culture of islets with adipocytes and pre-adipocytes did not impair insulin secretion. In situ evaluation of CD68-positive macrophages/monocytes in pancreatic resections suggested a positive correlation between the number of macrophages/monocytes within islets and the degree of steatosis. This result suggests that the fat cells, upon stimulation by fetuin-A and palmitate, augment macrophage/ monocyte infiltration via MCP-1 and IL-8. In agreement, a correlation of pancreatic steatosis with reduced insulin secretion is observed in humans with impaired glucose tolerance and fatty liver, the main source of fetuin-A and palmitate (Fig. 1 and $[4,8,36])$. Furthermore, this could be a reason why pancreatic fat is not a diabetes risk factor per se but depends on additional risk factors [3].

Fetuin-A stimulates IL-1 $\beta$ expression in islet-infiltrating macrophages through TLR4 It is well documented that beta cell death is triggered by cytotoxic cytokines [41-43] and may underlie the reduced beta cell mass of 

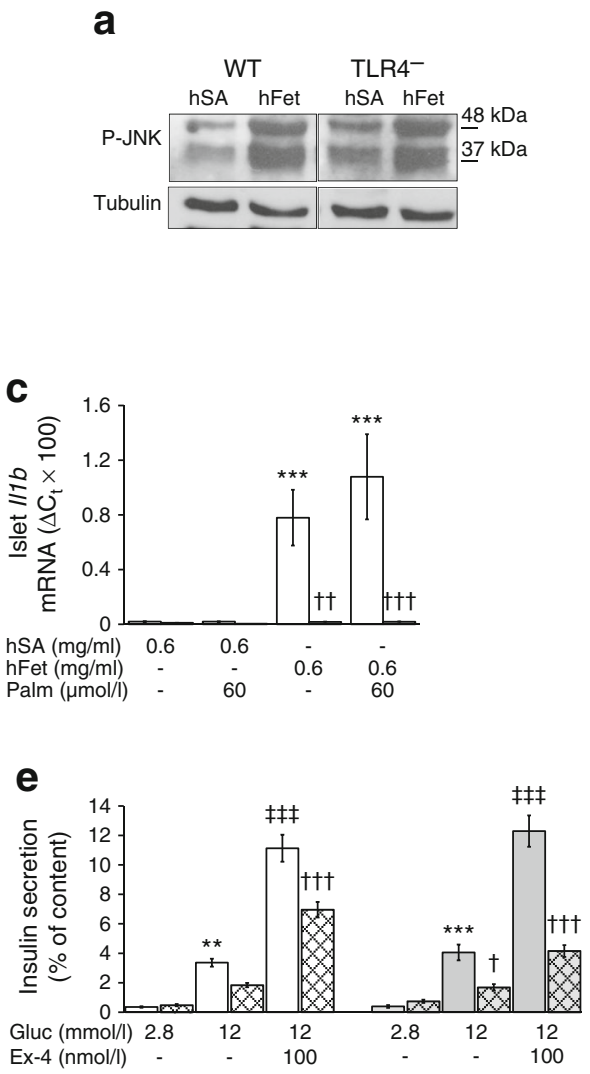

Fig. 5 Fetuin-A inhibits insulin secretion independent of TLR4. WT $(\mathrm{C} 3 \mathrm{H} / \mathrm{HeNCrl}$; white bars) and TLR4-defective $(\mathrm{C} 3 \mathrm{H} / \mathrm{HeJ}$; grey bars) mouse islets were cultured for (a, b) $1 \mathrm{~h}$ or $(\mathbf{c}, \mathbf{d}) 24 \mathrm{~h}$ with test substances as indicated. (a, b) Representative western blot of P-Thr183/Tyr185-JNK and mean \pm SEM of three independent experiments. (c, d) Relative mRNA levels $\left(\Delta C_{t}\right)$ of $I l l b$ and $I l 6$ presented as mean \pm SEM of three/ four independent experiments. Insulin secretion in isolated islets from (e, f) WT $(\mathrm{C} 3 \mathrm{H} / \mathrm{HeNCrl}$, white and hatched bars) and TLR4-defective $(\mathrm{C} 3 \mathrm{H} / \mathrm{HeJ}$; grey and grey-hatched bars) mice after 2 days culture in the

type 2 diabetic individuals [19,44]. Fetuin-A stimulated IL- $1 \beta$ expression in islets, and the effect was mediated by TLR4. The loss of IL-1 $\beta$ expression in human and mouse islets depleted of macrophages strongly suggests that fetuin-A-induced inflammation is exerted on resident macrophages, not on endocrine cells. Indeed, in human pancreatic resections, CD68-positive macrophages/ monocytes infiltrated the islets. In addition, we found no evidence that fetuin-A activates NF- $\mathrm{KB}$ in human islet cells, although a proinflammatory, TLR4-, JNK- and NF-KB-dependent effect of fetuin-A was recently ascribed to insulin secreting cells [45]. In agreement with our observations, another study identified islet resident macrophages as a source of cytokine production upon stimulation with TLR2/4 agonists [23]. Of note, fetuin-A binds LPS and NEFA with high affinity $[33,34,46]$. Although a fetuin-A preparation of high quality was used, it still contained low but detectable amounts of LPS (data not
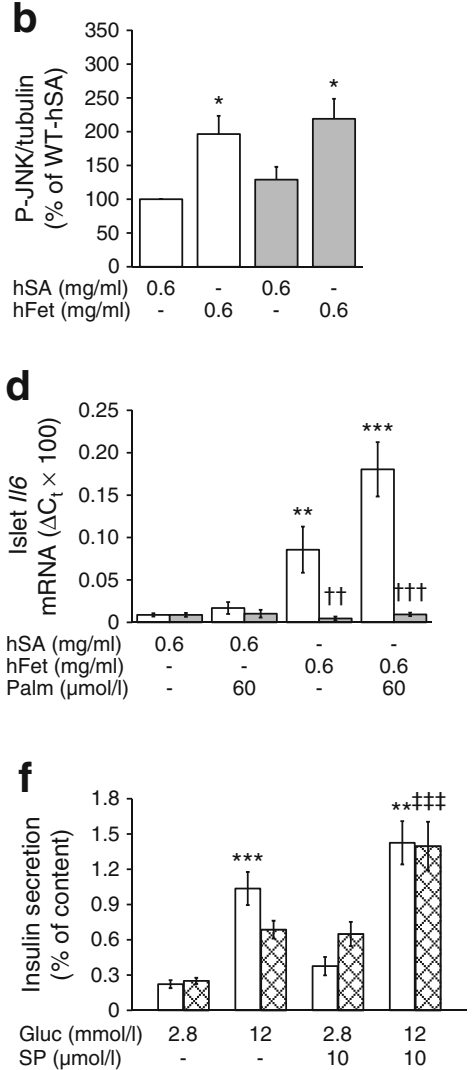

presence of hSA (white and grey bars) or fetuin-A (hatched bars). Test substances were added as indicated. Data are presented as mean \pm SEM of three to five independent experiments. ${ }^{*} p<0.05, * * p<0.01$, $* * * p<0.001$ vs respective hSA (b-d) or respective $2.8 \mathrm{mmol} / 1$ glucose (e, f); ${ }^{\dagger} p<0.05,{ }^{\dagger \dagger} p<0.01,{ }^{\dagger \dagger} p<0.001$ vs respective condition in WT islets $(\mathbf{c}, \mathbf{d})$ or respective hSA-cultured islets at the same condition $(\mathbf{e}, \mathbf{f})$; tt $p<0.001$ vs respective $12 \mathrm{mmol} / 1$ glucose. Ex-4, exendin-4 (GLP-1 analogue); Gluc, glucose; hFet, fetuin-A; palm, palmitate; SP, SP600125 (JNK inhibitor)

shown). Further experimental evidence is required to understand the mechanism how NEFA and LPS interact with fetuin-A to stimulate TLR4.

TLR4-independent and JNK-mediated inhibition of insulin secretion by fetuin-A The stimulation of IL-6 production by fetuin-A was TLR4-dependent and might augment insulin secretion [47]. The use of TLR4-defective mice enabled us to dissociate the inhibitory action of fetuin-A on insulin secretion from its effects on inflammation. The inhibition of insulin secretion by fetuin-A was TLR4-independent and implied JNK activation and the impairment of cellular $\mathrm{Ca}^{2+}$ homeostasis, since it was abolished by the JNK inhibitor SP600125 and by elevation of extracellular $\mathrm{Ca}^{2+}$ concentration. Accordingly, mice with constitutively active JNK in their beta cells displayed impaired GIIS and glucose intolerance [48]. Activation of JNK may indeed inhibit insulin secretion by reduction of $\mathrm{Ca}^{2+}$ influx [38]. In agreement 


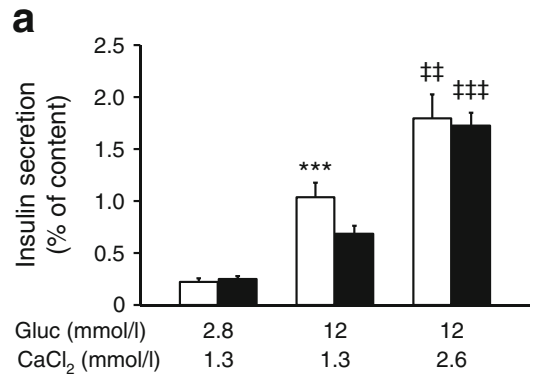

b

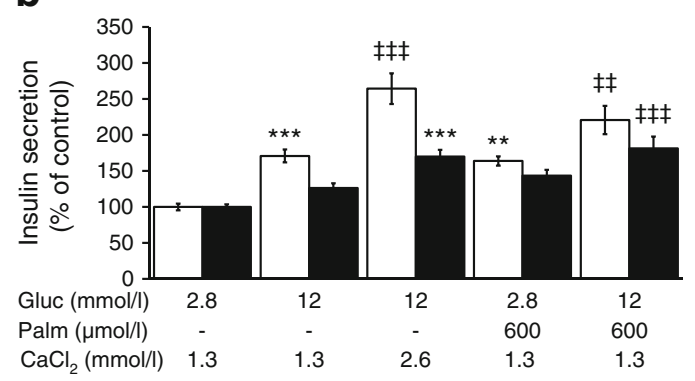

C

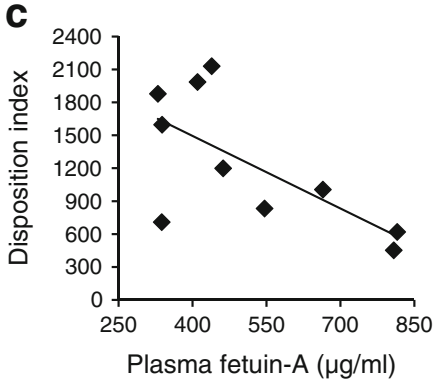

Fig. 6 Increasing extracellular $\mathrm{Ca}^{2+}$ overcomes fetuin-A inhibition of insulin secretion. Isolated islets from (a) WT (C57BL/6NCrl) mice and (b) human donors were cultured for 2 days in the presence of hSA (white bars) or fetuin-A (black bars) and, thereafter, insulin secretion was stimulated with test substances as indicated. Results are expressed as mean \pm SEM of three to five independent experiments, i.e. islet preparations. (c) Correlation between plasma fetuin-A and beta cell function in vivo expressed as disposition index in ten participants before surgery as described in the Methods $\left(R^{2}=0.45 ; p=0.033\right) . * * p<0.01$, $* * * p<0.001$ vs respective secretion at $2.8 \mathrm{mmol} / 1$ glucose; $* p<0.01$, $\$ p<0.001$ vs respective secretion at $12 \mathrm{mmol} / \mathrm{l}$ glucose and $1.3 \mathrm{mmol} / \mathrm{l}$ $\mathrm{CaCl}_{2}$. Gluc, glucose; palm, palmitate with our findings, fetuin-A impaired insulin secretion of the murine cell line $\beta$ TC6 [45]. Clinical data showing reduced insulin secretion in humans with increased levels of fetuin-A and the negative correlation between plasma fetuin- $\mathrm{A}$ and the disposition index (Fig. 6c), a variable for beta cell function adjusted for insulin sensitivity, support the inhibitory effect of fetuin-A on GIIS [27, 49]. In line with a negative effect of fetuin-A on secretion, fetal islets, that are exposed to higher concentrations of fetuin-A than adult islets, are less responsive to glucose [50]. Whether a twofold increase of plasma fetuin-A concentrations - such as can be observed in individuals with hepatic steatosis - is sufficient to impair GIIS in humans remains to be clarified.

In conclusion, these results suggest that the fatty liverderived fetuin-A impairs GIIS via a direct, TLR4-independent effect on beta cells and accentuates, in a TLR4-dependent manner, pancreatic inflammation by triggering a proinflammatory response in the pancreatic fat cells and islet macrophages/ monocytes (Fig. 7). These events may accelerate beta cell failure and the progression towards overt type 2 diabetes. a

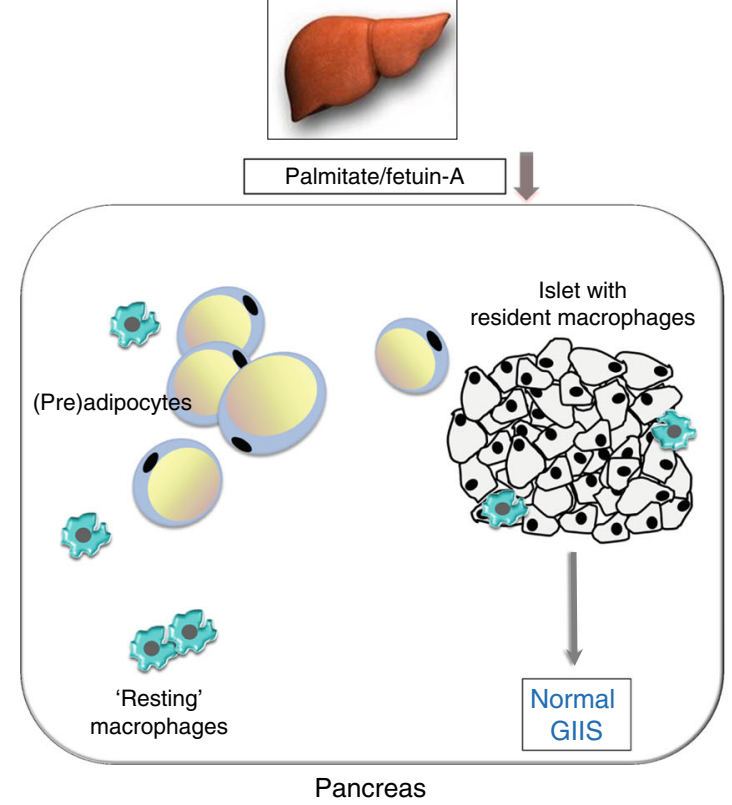

Fig. 7 Fatty liver-fatty pancreas crosstalk augments pancreatic inflammation and impairs insulin secretion. (a) In the absence of fatty liver, pancreatic fat cells are in a 'resting' state. (b) Fatty liver-derived fetuinA and palmitate stimulate pancreatic fat cells and islet resident b Fatty liver

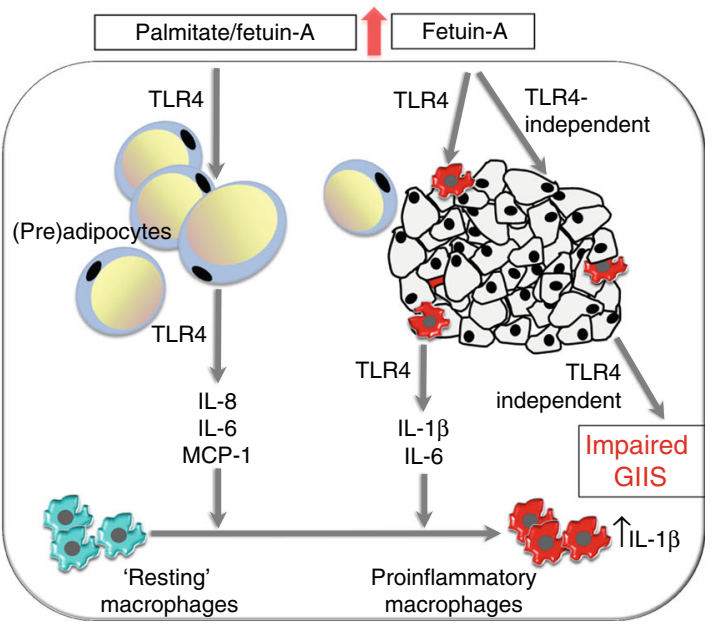

Pancreas

macrophages. The increased expression of chemo-attractants may augment macrophage/monocyte infiltration and expression of cytotoxic proinflammatory cytokines and islet cell death. In addition, fetuin-A affects insulin secretion in a TLR4-independent manner 
Acknowledgements We would like to thank S. Wagner and L. Metzler (Department of Surgery, University Hospital Tuebingen), and L. Fritsche and A. Desseker (HMGU/IDM Tuebingen) for participant recruitment and study management. We express our gratitude to U. Schmidt and K. Bekure (HMGU/IDM Tuebingen), S. Haug, E. Metzinger and B. Schreiner (University Hospital of Tuebingen, Department of Internal Medicine IV), and B. Pömmerl (University of Tuebingen, Department of Immunology, Interfaculty institute of Cell Biology) for their skilled technical assistance.

Data availability Data sharing not applicable to this article as no datasets were generated or analysed during the current study.

Funding This study was supported by a grant (01GI0925) from the German Federal Ministry of Education and Research (BMBF) to the German Center for Diabetes Research (DZD e.V.). Human islets were provided by the JDRF award 31-2008-416 (ECIT Islet for Basic Research Programme) from Islet Transplantation Centres (Geneva, Milano, Lille).

Duality of interest The authors declare that there is no duality of interest associated with this manuscript.

Contribution statement FG, SU and DSA conceived, designed and performed experiments, analysed the data, prepared the figures and wrote the manuscript. MP and GK performed the RT-PCR experiments and analysed data. RW, MH, JM and MNB recruited and characterised participants, performed MRI and OGTT measurements, and analysed the data. AK, CT, SN, FF and BS implemented and coordinated the recruitment of participants and performed histological tissue analyses. TS implemented, managed and performed the genotyping of the mouse colony and contributed to the revision of the manuscript. NS, AF and HUH established the human cohorts, contributed to the design of the study and to the discussion of the manuscript. All authors corrected, revised and approved the final version of the manuscript. FG and SU are the guarantors of this work and, as such, had full access to all the data of the study and take responsibility for the integrity of the data and the accuracy of the data analysis.

\section{References}

1. Lingvay I, Esser V, Legendre JL et al (2009) Noninvasive quantification of pancreatic fat in humans. J Clin Endocrinol Metab 94: 4070-4076

2. Hollingsworth KG, Al Mrabeh A, Steven S, Taylor R (2015) Pancreatic triacylglycerol distribution in type 2 diabetes. Diabetologia 58:2676-2678

3. Yamazaki H, Tsuboya T, Katanuma A et al (2016) Lack of independent association between fatty pancreas and incidence of type 2 diabetes mellitus: 5-year Japanese cohort study. Diabetes Care 39: $1677-1683$

4. Heni M, Machann J, Staiger H et al (2010) Pancreatic fat is negatively associated with insulin secretion in individuals with impaired fasting glucose and/or impaired glucose tolerance: a nuclear magnetic resonance study. Diabetes Metab Res Rev 26:200-205

5. Pinnick KE, Collins SC, Londos C, Gauguier D, Clark A, Fielding BA (2008) Pancreatic ectopic fat is characterized by adipocyte infiltration and altered lipid composition. Obesity 16:522-530
6. Tushuizen ME, Bunck MC, Pouwels PJ et al (2007) Pancreatic fat content and $\beta$-cell function in men with and without type 2 diabetes. Diabetes Care 30:2916-2921

7. Szczepaniak LS, Victor RG, Mathur R et al (2012) Pancreatic steatosis and its relationship to beta-cell dysfunction in humans: racial and ethnic variations. Diabetes Care 35:2377-2383

8. Begovatz P, Koliaki C, Weber K et al (2015) Pancreatic adipose tissue infiltration, parenchymal steatosis and beta cell function in humans. Diabetologia 8:1646-1655

9. Stefan N, Häring HU (2013) The role of hepatokines in metabolism. Nat Rev Endocrinol 9:144-152

10. Donath MY, Shoelson SE (2011) Type 2 diabetes as an inflammatory disease. Nat Rev Immunol 11:98-107

11. Poitout V, Amyot J, Semache M, Zarrouki B, Hagman D, Fontes G (2010) Glucolipotoxicity of the pancreatic beta cell. Biochim Biophys Acta 1801:289-298

12. Srinivas PR, Wagner AS, Reddy LV et al (1993) Serum $\alpha_{2}-\mathrm{HS}$ glycoprotein is an inhibitor of the human insulin receptor at the tyrosine kinase level. Mol Endocrinol 7:1445-1455

13. Mathews ST, Chellam N, Srinivas PR et al (2000) $\alpha_{2}-\mathrm{HSG}$, a specific inhibitor of insulin receptor autophosphorylation, interacts with the insulin receptor. Mol Cell Endocrinol 164:87-98

14. Goustin AS, Abou-Samra AB (2011) The "thrifty" gene encoding AHSG/fetuin-A meets the insulin receptor: insights into the mechanism of insulin resistance. Cell Signal 23:980-990

15. Kahn SE, Cooper ME, Del Prato S (2014) Pathophysiology and treatment of type 2 diabetes: perspectives on the past, present, and future. Lancet 383:1068-1083

16. Meier JJ, Breuer TG, Bonadonna RC et al (2012) Pancreatic diabetes manifests when beta cell area declines by approximately $65 \%$ in humans. Diabetologia 55:1346-1354

17. Talchai C, Xuan S, Lin HV, Sussel L, Accili D (2012) Pancreatic beta cell dedifferentiation as a mechanism of diabetic beta cell failure. Cell 150:1223-1234

18. Gao T, McKenna B, Li C et al (2014) Pdx1 maintains beta cell identity and function by repressing an alpha cell program. Cell Metab 19:259-271

19. Prentki M, Nolan CJ (2006) Islet beta cell failure in type 2 diabetes. J Clin Invest 116:1802-1812

20. Igoillo-Esteve M, Marselli L, Cunha DA et al (2010) Palmitate induces a pro-inflammatory response in human pancreatic islets that mimics CCL2 expression by beta cells in type 2 diabetes. Diabetologia 53:1395-1405

21. Hennige AM, Ranta F, Heinzelmann I et al (2010) Overexpression of kinase-negative protein kinase $\mathrm{C} \delta$ in pancreatic $\beta$-cells protects mice from diet-induced glucose intolerance and $\beta$-cell dysfunction. Diabetes 59:119-127

22. Eguchi K, Manabe I, Oishi-Tanaka Y et al (2012) Saturated fatty acid and TLR signaling link beta cell dysfunction and islet inflammation. Cell Metab 15:518-533

23. Nackiewicz D, Dan M, He W et al (2014) TLR2/6 and TLR4activated macrophages contribute to islet inflammation and impair beta cell insulin gene expression via IL-1 and IL-6. Diabetologia 57:1645-1654

24. Ehses JA, Perren A, Eppler E et al (2007) Increased number of isletassociated macrophages in type 2 diabetes. Diabetes 56:2356-2370

25. Richardson SJ, Willcox A, Bone AJ, Foulis AK, Morgan NG (2009) Islet-associated macrophages in type 2 diabetes. Diabetologia 52:1686-1688

26. Stefan N, Hennige AM, Staiger $\mathrm{H}$ et al (2006) $\alpha_{2}$-HeremansSchmid glycoprotein/fetuin-A is associated with insulin resistance and fat accumulation in the liver in humans. Diabetes Care 29:853857

27. Stefan N, Häring HU (2013) Circulating fetuin-A and free fatty acids interact to predict insulin resistance in humans. Nat Med 19: 394-395 
28. Cayatte AJ, Kumbla L, Subbiah MT (1990) Marked acceleration of exogenous fatty acid incorporation into cellular triglycerides by fetuin. J Biol Chem 265:5883-5888

29. Pal D, DasGupta S, Kundu R et al (2012) Fetuin-A acts as an endogenous ligand of TLR4 to promote lipid-induced insulin resistance. Nat Med 18:1279-1285

30. Siegel-Axel DI, Ullrich S, Stefan N et al (2014) Fetuin-A influences vascular cell growth and production of proinflammatory and angiogenic proteins by human perivascular fat cells. Diabetologia 57 : 1057-1066

31. Chatterjee P, Seal S, Mukherjee S et al (2013) Adipocyte fetuin-A contributes to macrophage migration into adipose tissue and polarization of macrophages. J Biol Chem 288:28324-28330

32. Brylka L, Jahnen-Dechent W (2013) The role of fetuin-A in physiological and pathological mineralization. Calcif Tissue Int 93:355364

33. Ombrellino M, Wang H, Yang H et al (2001) Fetuin, a negative acute phase protein, attenuates TNF synthesis and the innate inflammatory response to carrageenan. Shock 15:181-185

34. Wang H, Sama AE (2012) Anti-inflammatory role of fetuin-A in injury and infection. Curr Mol Med 12:625-633

35. Stefan N, Ramsauer M, Jordan P et al (2014) Inhibition of $11 \beta$ HSD1 with RO5093151 for non-alcoholic fatty liver disease: a multicentre, randomised, double-blind, placebo-controlled trial. Lancet Diabetes Endocrinol 2:406-416

36. Stefan N, Sun Q, Fritsche A et al (2014) Impact of the adipokine adiponectin and the hepatokine fetuin-A on the development of type 2 diabetes: prospective cohort- and cross-sectional phenotyping studies. PLoS One 9:e92238

37. Bosco D, Armanet M, Morel $P$ et al (2010) Unique arrangement of $\alpha$ - and $\beta$-cells in human islets of Langerhans. Diabetes 59:12021210

38. Kim HE, Choi SE, Lee SJ et al (2008) Tumour necrosis factor- $\alpha$ induced glucose-stimulated insulin secretion inhibition in INS-1 cells is ascribed to a reduction of the glucose-stimulated $\mathrm{Ca}^{2+}$ influx. J Endocrinol 198:549-560

39. Wernstedt AI, Tao C, Morley TS et al (2014) Adipocyte inflammation is essential for healthy adipose tissue expansion and remodeling. Cell Metab 20:103-118
40. Klemm DJ, Leitner JW, Watson P et al (2001) Insulin-induced adipocyte differentiation. Activation of CREB rescues adipogenesis from the arrest caused by inhibition of prenylation. J Biol Chem 276:28430-28435

41. Maedler K, Sergeev P, Ris F et al (2002) Glucose-induced beta cell production of IL-1 $\beta$ contributes to glucotoxicity in human pancreatic islets. J Clin Invest 110:851-860

42. Donath MY, Ehses JA, Maedler K et al (2005) Mechanisms of $\beta$-cell death in type 2 diabetes. Diabetes 54(Suppl 2):S108S113

43. Ehses JA, Boni-Schnetzler M, Faulenbach M, Donath MY (2008) Macrophages, cytokines and $\beta$-cell death in type 2 diabetes. Biochem Soc Trans 36:340-342

44. Meier JJ, Bonadonna RC (2013) Role of reduced $\beta$-cell mass versus impaired $\beta$-cell function in the pathogenesis of type 2 diabetes. Diabetes Care 36(Suppl 2):S113-S119

45. Shen X, Yang L, Yan S et al (2015) Fetuin A promotes lipotoxicity in beta cells through the TLR4 signaling pathway and the role of pioglitazone in anti-lipotoxicity. Mol Cell Endocrinol 412:1-11

46. Dziegielewska KM, Andersen NA, Saunders NR (1998) Modification of macrophage response to lipopolysaccharide by fetuin. Immunol Lett 60:31-35

47. da Silva KM, Bittencourt A, de Bittencourt PIH et al (2012) Physiological concentrations of interleukin- 6 directly promote insulin secretion, signal transduction, nitric oxide release, and redox status in a clonal pancreatic $\beta$-cell line and mouse islets. $\mathrm{J}$ Endocrinol 214:301-311

48. Lanuza-Masdeu J, Arevalo MI, Vila C, Barbera A, Gomis R, Caelles C (2013) In vivo JNK activation in pancreatic $\beta$-cells leads to glucose intolerance caused by insulin resistance in pancreas. Diabetes 62:2308-2317

49. Bergman RN, Ader M, Huecking K, van Citters G (2002) Accurate assessment of $\beta$-cell function: the hyperbolic correction. Diabetes 51(Suppl 1):S212-S220

50. Kawazu S, Kanazawa Y, Hayashi M, Ikeuchi M, Nakai T, Kosaka K (1980) Monolayer culture of human fetal and adult pancreas. Static and dynamic studies of insulin release in vitro. Horm Metab Res 12:354-360 